\title{
Importance and role of pharmacokinetics, pharmacodynamics and stability in nonhospital, community-based parenteral antimicrobial therapy
}

Kathryn Slayter BSc (Pharm) PharmD

$S^{2}$ everal variables including the likely infecting organism, pharmacokinetic (PK) and pharmacodynamic factors (PD), and drug stability must be considered when selecting antimicrobials. The goal of antibiotic therapy is to provide adequate drug concentration at the site of infection long enough to eliminate the pathogen. Almost any antimicrobial can be used for outpatient therapy, but drugs with long half-lives are the best suited. The use of agents that can be administered once or twice daily minimized the disruption of daily activities and limited the number of intravenous line manipulations, lessening the potential for catheter-associated complications (1-3). Ceftriaxone (Rocephin, Hoffmann La Roche Limited, Mississauga, Ontario) and other cephalosporins have been the most common drugs reported in the literature (4). If the antibiotic must be given every 2,4 , or $6 \mathrm{~h}$, it may become impractical to give at home without the aid of an infusion pump. Not all Canadian centres use pumps because they are complicated for patients to use and are expensive $(1,5)$.

\section{PHARMACOKINETICS AND PHARMACODYNAMICS}

New insights into PK and PD parameters have resulted in changes in antibotic dosing (6). Bacterial killing can be classified as concentration dependent or time dependent, with spe- cific differences among antibiotic classes. The antimicrobial activity of the drug may be assessed by several other PD criteria including minimum inhibitory concentration (MIC), postantibiotic effect (PAE) (ie, the extended suppression of bacterial growth after antibiotic exposure) and the postantibiotic leukocyte enhancement effect (in which pathogens become more susceptible to the activity of leukocytes). Major factors affecting the duration or presence of PAE are the type of microorganism and the type of antimicrobial used $(6,7)$.

In general, the antimicrobial agents can be divided into three categories based on their PD activity $(1,2)$ (Table 1). Whereas most other antimicrobials inhibit protein synthesis at ribosomal sites, the beta-lactam antibiotics interfere with the synthesis of antimicrobial cell walls. Unlike aminoglycosides, where serum concentration is important, the bactericidal action of beta-lactams is related to the time that the serum concentration is above the MIC. High doses do not increase their potency or rate of bactericidal activity. Once plasma concentrations of penicillins or cephalosporins fall below the MIC, susceptible organisms begin to reproduce within a few hours. Furthermore, the beta-lactam drugs, apart from the carbapenems, have little or no PAE with Gram-negative organisms (7). Therefore, certain cephalosporins and penicillins 
TABLE 1

Antimicrobial pharmacodynamics effect on dosing

\begin{tabular}{|c|c|c|}
\hline Antibiotic & Pharmacodynamics & Goal \\
\hline $\begin{array}{l}\text { Penicillins } \\
\text { Cephalosporins } \\
\text { Aztreonam }\end{array}$ & $\begin{array}{l}\text { Time-dependent } \\
\text { killing, brief or } \\
\text { no PAE }\end{array}$ & $\begin{array}{l}\text { Maximize exposure } \\
\text { time, Keep serum } \\
\text { levels greater than } \\
\text { MIC }\end{array}$ \\
\hline $\begin{array}{l}\text { Carbapenems } \\
\text { Vancomycin } \\
\text { Clindamycin } \\
\text { Macrolides }\end{array}$ & $\begin{array}{l}\text { Time-dependent } \\
\text { killing, prolonged } \\
\text { PAE }\end{array}$ & $\begin{array}{l}\text { Maximize exposure } \\
\text { time, serum levels } \\
\text { can fall below MIC }\end{array}$ \\
\hline Aminoglycosides & $\begin{array}{l}\text { Concentration- } \\
\text { dependant killing, } \\
\text { prolonged PAE }\end{array}$ & $\begin{array}{l}\text { Maximize } \\
\text { concentration, } \\
\text { attain peak serum } \\
\text { level }\end{array}$ \\
\hline
\end{tabular}

Quinolones

Metronidazole

Adapted from reference 2. MIC Minimum inhibitory concentration;

PAE Postantibiotic effect

with half-lives of less than 60 mins need to be dosed frequently to maintain the trough concentration above the MIC for the majority of the dosing interval (2) (Table 2). It is suggested that these agents are more appropriately given by continuous infusion rather than in intermittent doses; however, this can be logistically impossible in the ambulatory setting. In this instance, a programmable pump that delivers a continuous infusion may be beneficial. Continuous infusion may also require less drug because there is no advantage to having maintenance levels greater than four times the MIC of susceptible organisms $(3,8)$.

Ceftriaxone has a sufficiently long half-life to provide serum concentrations above the MIC for susceptible organisms for $24 \mathrm{~h}$ and, thus, can be given once daily. This pharmacokinetic property makes ceftriaxone's use advantageous because it can be used in the emergency room for patients who will not be admitted to hospital to provide them with $24 \mathrm{~h}$ of intravenous antibiotic coverage. The drug also is conveniently administered in the patient's home environment.

Other categories of antibacterial agents that are also effective above the MIC include the carbapenems, vancomycin, clindamycin and the macrolides. These drugs have more persistent PAE and, therefore, serum levels may be allowed to drop below the MIC. The carbapenems have exhibited PAEs of up to several hours with Gram-negative bacilli (7). Carbapenems attain their maximum efficacy when serum levels are above the MIC for only about $50 \%$ of the dosing interval (5). Vancomycin, with a long half-life and persistent PAE, only requires dosing every $12 \mathrm{~h}$ to $24 \mathrm{~h}$ and, tdherefore, is very convenient in the outpatient setting. However, increasing concern about vancomycin-resistant enterococci and Staphylococcus aureus has limited vancomycin therapy to selected situations to deter its overuse. Vancomycin should no longer be used simply because it is convenient to give in the setting of impaired renal function when one can dose the drug only every few days (9).

The aminoglycosides, quinolones and metronidazole have concentration-dependent killing and a prolonged PAE. Once
TABLE 2

Half-lives of common parenteral antibiotics

\begin{tabular}{lc}
\hline Drug & Half-life (h) \\
\hline Amikacin & $2-3$ \\
Ampicillin & $1-1.5$ \\
Aztreonam & 1.7 \\
Cefazolin & $1-2$ \\
Cefotaxime & $1-2$ \\
Ceftazidime & $1.5-2$ \\
Ceftriaxone & $5.5-11$ \\
Cefuroxime & $1-2$ \\
Ciprofloxacin & $3-5$ \\
Clindamycin & $2-3$ \\
Cloxacillin & 0.5 \\
Doxycycline & $14-25$ \\
Ganciclovir & 2.9 \\
Gentamicin & $2-3$ \\
Imipenem/cilastatin & 1 \\
Meropenem & 1 \\
Metronidazole & $6-14$ \\
Penicillin & 0.5 \\
Piperacillin & $0.5-1.5$ \\
Piperacillin/tazobactam & $0.7-1.2$ \\
Ticarcillin & 1 \\
Ticarcillin/clavulanate & 1 \\
Tobramycin & $2-3$ \\
Trimethoprim/sulphamethoxazole & $4-6$ \\
Vancomycin &
\end{tabular}

Adapted from reference 1

daily administration of aminoglycosides has become popular in most institutions due to its practicality. The rationale for once daily aminoglycosides is fourfold. First, aminoglycosides demonstrate concentration-dependent bacterial killing, meaning that the greater bactericidal activity is achieved with higher concentrations. Second, they possess a prolonged PAE for most Gram-negative organisms. This PAE has been demonstrated to increase with increasing doses. These two properties alone are advantages to administer larger doses less frequently $(7,10)$. Third, aminoglycosides induce adaptive resistance in Gram-negative bacteria. Adaptive resistance allows bacteria previously exposed to the continued presence of aminoglycosides to downregulate drug uptake. Once daily administration may lead to more effective killing by allowing less contact time between the antimicrobial and the organism, thus allowing less opportunity for postexposure resistance to develop (11). Finally, it appears that nephrotoxicity is a result of the accumulation of the aminoglycoside in the renal cortex. The uptake of aminoglycosides into the renal tubular cells appears to be saturable process. Animal and human studies have shown that the aminoglycoside concentration in the renal cortex is lower when administered as a single dose than when the same dose is given in multiple doses given more frequently. Clinical studies have demonstrated a decrease in nephrotoxicity or no significant difference compared with conventional 
dosing. The use of once daily aminoglycosides in pregnant women, children, burn patients, and patients with ascites and endocarditis, however, has not been intensively studied $(10,12,13)$.

\section{STABILITY}

To ensure the safety and efficacy of a nonhospital, community-based parenteral antimicrobial program, stability of the antimicrobial in question must be assured (Table 3). A drug is considered stable in solution if it retains $90 \%$ or more of its original concentration for a minimum of $24 \mathrm{~h}$ at room temperature $\left(25^{\circ} \mathrm{C}\right)$ and four to seven days under refrigeration ( 3 to $5^{\circ} \mathrm{C}$ ). Imipenem/cilastatin (Primaxin, Merck Sharpe \& Dohme Canada, Kirkland, Quebec), ampicillin and trimethoprim/sulfamethoxazole (TMP/SMX) are stable for less than $24 \mathrm{~h}$ in solution, which is of some concern unless the patients themselves are reconstituting the antimicrobials before infusion. The stability of TMP/SMX is reduced because the concentration is increased; therefore, this combination should not be used in devices with reservoir volumes less than $250 \mathrm{~mL}$ unless it is reconstituted and infused immediately. Furthermore, this drug may precipitate at temperatures of 3 to $5^{\circ} \mathrm{C}(14,15)$. Imipenem is stable at room temperature for $10 \mathrm{~h}$ and in the refrigerator for two days. Meropenem (Merrem, Astra Zeneca, Mississauga, Ontario) the newest carbapenem, has prolonged stability at lower temperatures and requires little intravenous solution for infusion due to its hydrophilicity. One gram can be administered in as little as $20 \mathrm{~mL}$ of sterile water over 5 mins or it can be hung as a regular infusion over 20 to 30 mins. In addition, it does not appear to share with imipenem the high incidence of nausea when given rapidly (16). These attributes may, therefore, make its use more attractive in the outpatient setting for complicated polymicrobial infections.

\section{REFERENCES}

1. Tice A. Handbook of Outpatient Parenteral Therapy for Infectious Diseases. New York: Scientific American Inc, 1997:43-55.

2. Craig WA. Kinetics of antibiotics in relation to effective and convenient outpatient parenteral treatment. Int J Antimicrob Agent 1995;5:19-22.

3. Visser LG, Arnouts P, van Furth R, Mattie H, van den Broek PJ. Clinical pharmacokinetics of continuous intravenous administration of penicillins. Clin Infect Dis 1993;17:491-5.

4. Williams DN, Rehm SJ, Tice AD, Bradley JS, Kind AC, Craig WA. Practice guidelines for community-based parenteral anti-infective therapy. Clin Infect Dis 1997;25:787-801.

5. Craig WA. Selecting the antibiotic. Hosp Pract 1993;28(Suppl 1):16-20.

6. Ebert SC, Craig WA. Pharmacodynamic properties of antibiotics: Application to drug monitoring and dosage regimen design. Infect Contr Hosp Epidemiol 1990;11:319-26.

7. Craig WA, Vogelmen B. The postantibiotic effect. Ann Intern Med 1987;106:900-2.

8. Craig WA, Ebert SC. Continuous infusion of B-lactam antibiotics. Antimicrob Agents Chemother 1992;36:2577-83.

9. Centres for Disease Control and Prevention. Preventing the spread of vancomycin resistance-Report from the Hospital Infection Control Practices Advisory Committee. 59 Fed Reg $25,757(1994)$.
TABLE 3

Antimicrobial stability

\begin{tabular}{|c|c|c|c|}
\hline \multicolumn{4}{|c|}{ Dilution } \\
\hline Antibiotic & NS or D5W & $5^{\circ} \mathrm{C}$ (days) & $25^{\circ} \mathrm{C}$ (days) \\
\hline Amikacin & $0.25-5 \mathrm{mg} / \mathrm{mL}$ & 60 & 1 \\
\hline Ampicillin & 30 mg/mL (NS) & 2 & $8 \mathrm{~h}$ \\
\hline Aztreonam & $20 \mathrm{mg} / \mathrm{mL}$ & 7 & 2 \\
\hline Cefazolin & $10-20 \mathrm{mg} / \mathrm{mL}$ & 10 & 1 \\
\hline Cefotaxime & 10 mg/mL & 22 & 1 \\
\hline Ceftazidime & $1-40 \mathrm{mg} / \mathrm{mL}$ & 7 & 1 \\
\hline Ceftriaxone & $10-40 \mathrm{mg} / \mathrm{mL}$ & 10 & 3 \\
\hline Cefuroxime & 5-10 mg/mL & 30 & 1 \\
\hline Ciprofloxacin & $1-2 \mathrm{mg} / \mathrm{mL}$ & 14 & 14 \\
\hline Clindamycin & $6-12 \mathrm{mg} / \mathrm{mL}$ & 32 & 16 \\
\hline Cloxacillin & $20 \mathrm{mg} / \mathrm{mL}$ & 14 & 1 \\
\hline Doxycycline & $0.1-1 \mathrm{mg} / \mathrm{mL}$ & 3 & 2 \\
\hline Ganciclovir & $1-10 \mathrm{mg} / \mathrm{mL}(\mathrm{D} 5 \mathrm{~W})$ & 35 & - \\
\hline \multirow[t]{2}{*}{ Gentamicin } & $1-5.5 \mathrm{mg} / \mathrm{mL}$ & $4-30$ & $2-30$ \\
\hline & (D5W) & 2 & $10 \mathrm{~h}$ \\
\hline \multirow[t]{2}{*}{ Imipenem/cilastatin } & $2.5-5 \mathrm{mg} / \mathrm{mL}$ & $2-7$ & $10 \mathrm{~h}$ \\
\hline & (NS) & - & Premixed \\
\hline Meropenem & $1-40 \mathrm{mg} / \mathrm{mL}$ & 14 & 3 \\
\hline Metronizaxole* & Premixed & 7 & 1 \\
\hline \multirow[t]{2}{*}{ Penicillin } & 0.2 million $\mathrm{U} / \mathrm{mL}$ & 7 & 1 \\
\hline & $(\mathrm{SW})$ & 7 & 1 \\
\hline Piperacillin & 10-80 mg/mL & 7 & 1 \\
\hline Piperacillin/tazo & 10-80 mg/mL & - & $2-6 \mathrm{~h}$ \\
\hline \multirow[t]{2}{*}{ Ticarcillin } & $10-100 \mathrm{mg} / \mathrm{mL}$ & 4 & 2 \\
\hline & $(\mathrm{NS})$ & $14-63$ & $1-17$ \\
\hline $\begin{array}{l}\text { Ticarcillin/ } \\
\text { clavulanate }\end{array}$ & $\begin{array}{c}10-100 \mathrm{mg} / \mathrm{mL} \\
(\mathrm{NS})\end{array}$ & & \\
\hline TMP/SMX* & $\begin{array}{c}0.65-1.1 \mathrm{mg} / \mathrm{mL} \\
\text { (TMP) }\end{array}$ & & \\
\hline Tobramycin & $\begin{array}{c}0.2-3 \mathrm{mg} / \mathrm{mL} \\
(\mathrm{D} 5 \mathrm{~W})\end{array}$ & & \\
\hline Vancomycin & $2.5-10 \mathrm{mg} / \mathrm{mL}$ & & \\
\hline
\end{tabular}

Adapted from references $1,14 .{ }^{*}$ Do not refrigerate. D5W Dextrose in water; NS Normal Saline; SW Sterial water; TMP/SMX Trimethoprim/ sulphamethoxazole

10. Preston SL, Briceland L. Single daily dosing of aminoglycosides. Pharmacotherapy 1995;15:297-316.

11. Barclay ML, Begg EJ, Chambers ST. Adaptive resistance following single doses of gentamicin in a dynamic in vitro model. Antimicrob Agents Chemother 1992;36:1951-7.

12. Prins JM, Buller HR, Kuijper EJ, Tange RA, Speelman P. Once versus thrice daily gentamicin in patients with serious infections. Lancet 1993;341:335-9.

13. Ali MZ, Goetz MB. A meta-analysis of the relative efficacy and toxicity of single daily dosing versus multiple daily dosing of aminoglycosides. Clin Infect Dis 1997;24:796-809.

14. Trissel LA. Handbook on Injectable Drugs, 9th edn. Bethesda: American Society of Health-System Pharmacists, 1996.

15. Gilbert DN, Dworkin RJ, Raber SR, Leggett JE. Outpatient parenteral antimicrobial-drug therapy. $\mathrm{N}$ Engl J Med 1997;337:829-38.

16. Product Monograph, Meropenem. Mississauga: Zeneca Pharma Inc, 1997. 


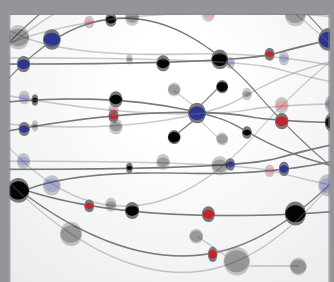

The Scientific World Journal
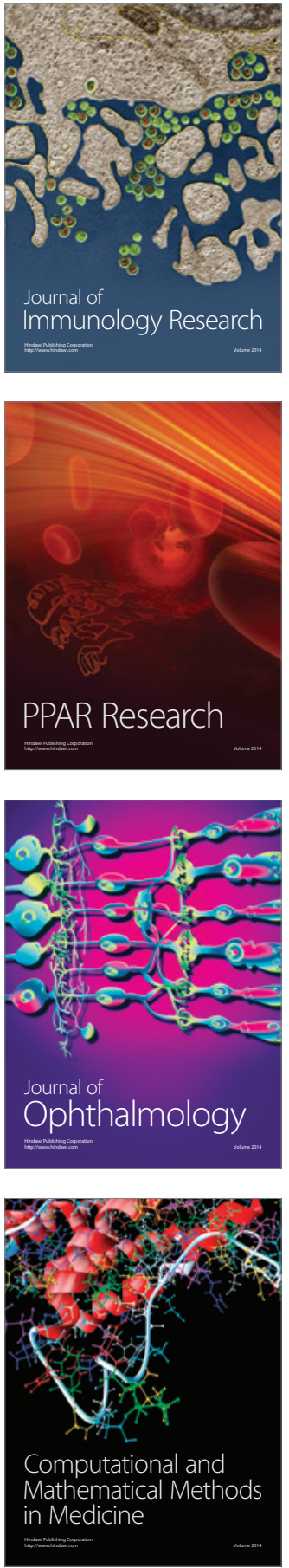

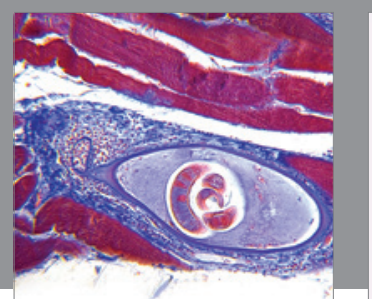

Gastroenterology Research and Practice

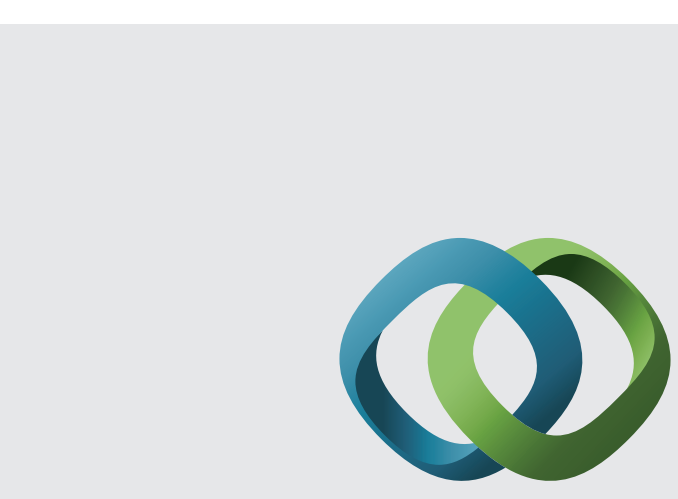

\section{Hindawi}

Submit your manuscripts at

http://www.hindawi.com
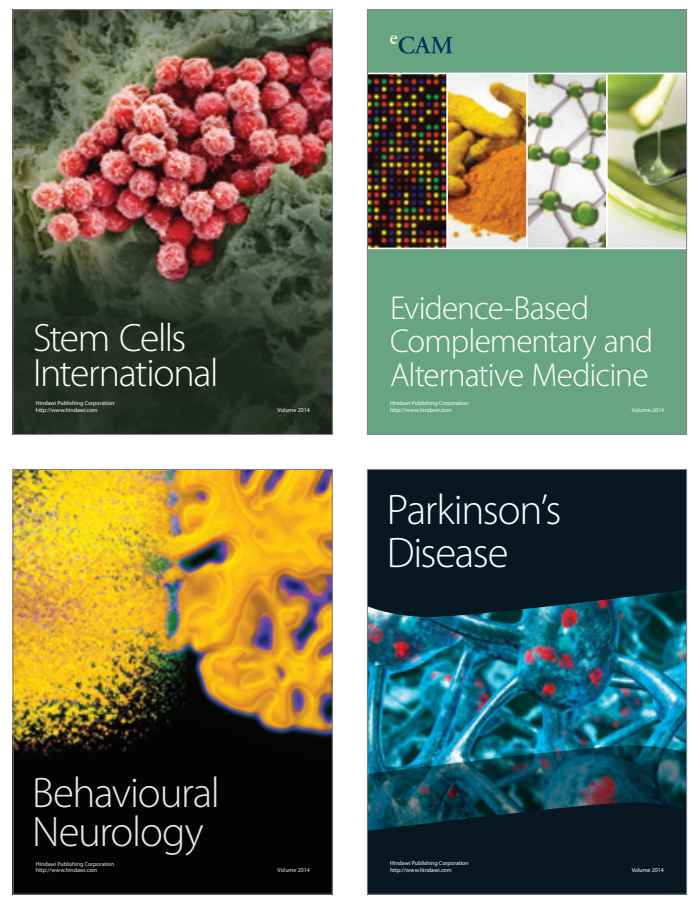
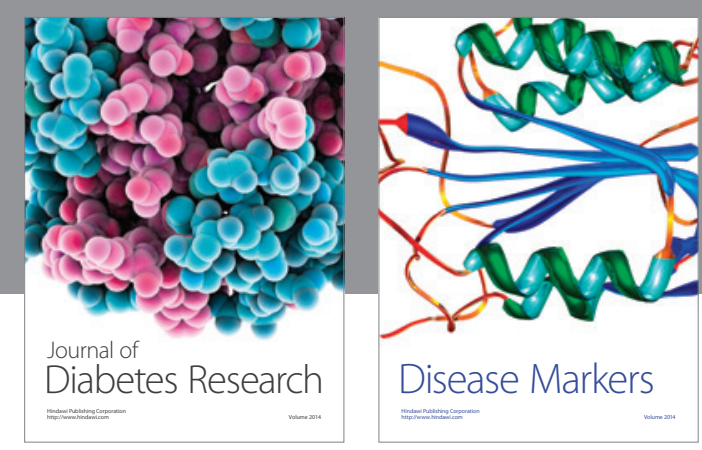

Disease Markers
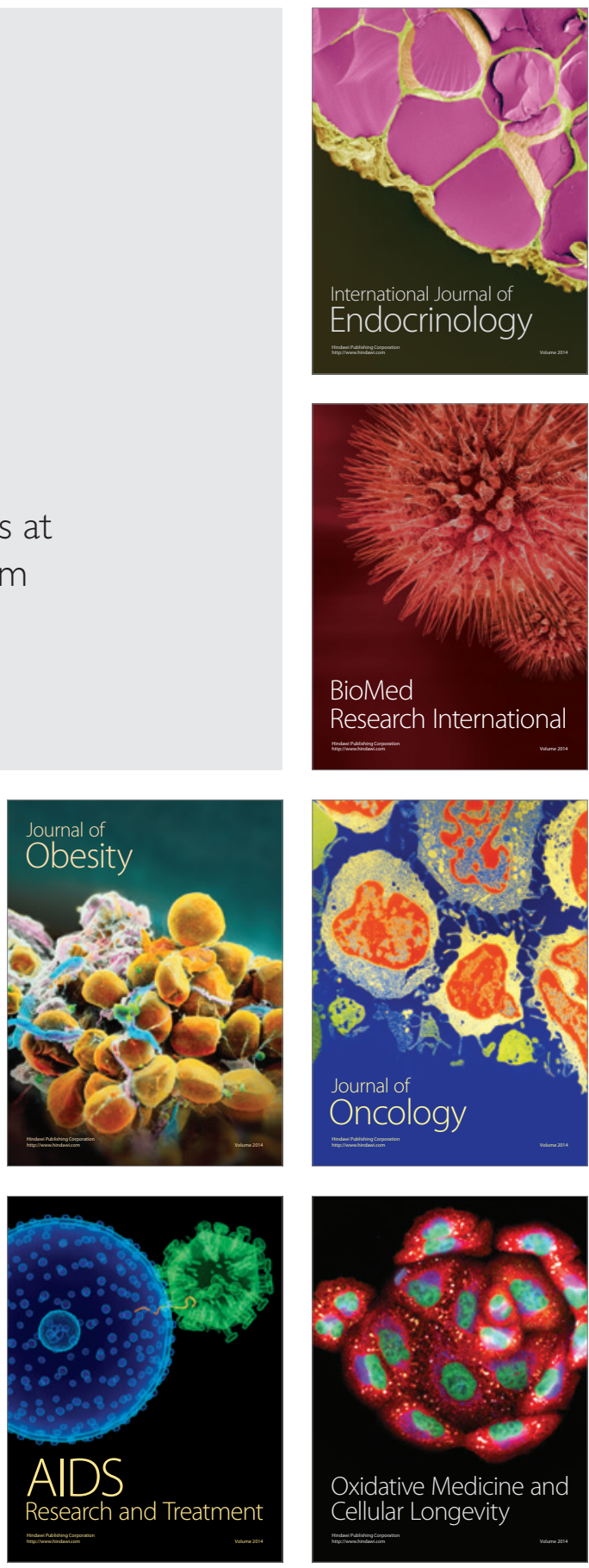